\title{
Chapter 6 \\ Access to Social Protection by Immigrants, Emigrants and Resident Nationals in Ecuador
}

\author{
Analía Minteguiaga and Valerie Carmel
}

\subsection{Overview of the Welfare System and Main Migration Features in Ecuador}

This chapter aims to present and analyse Ecuador's welfare system and access to social protection benefits across five policy areas: unemployment, health care, family benefits, pensions, and guaranteed minimum resources. Special emphasis is placed on eligibility requirements for migrants, both foreigners residing in the country and nationals residing abroad. We start with a brief introduction regarding the main features of the country's welfare system and the main patterns of migration to contextualize state intervention and social protection. We later identify the main contributory and non-contributory social protection benefits to examine the principles that inform them, eligibility criteria, inclusion or exclusion of migrants, among others.

\footnotetext{
A. Minteguiaga $(\bowtie)$

Instituto de Altos Estudios Nacionales, Ecuador/Grupo de Estudio sobre Políticas Sociales y Condiciones de Trabajo del Instituto de Investigaciones Gino Germani, Universidad de Buenos Aires, Buenos Aires, Argentina

V. Carmel ( $\triangle)$

Flacso-Ecuador, Quito, Ecuador
} 


\subsubsection{Main Characteristics of the National Social Protection System}

Scholarly work on social protection and welfare in Ecuador has mostly provided fragmented contributions on social policy areas like education (Ponce 1997, 2010), health (Velasco 2011; Estrella and Crespo-Burgos 2002), labour (Porras 2010; Serrano 2013) or specific social programs (Naranjo 2008; Ponce et al. 2013; León 2002; León and Alomia 2008). It has also favoured a quantitative approach focused on spending and the general argument that the public-state sphere is the sole producer of welfare (Ponce and Drouet 2017; Vos 2000; Vos et al. 2002). However, a series of comparative regional studies shed light on the main characteristics of Ecuador's social protection system.

Barrientos (2004), for example, stresses that informality must be at the centre of the characterization of welfare regimes in Latin America because of low levels of labour insertion leading to low levels of inclusion in social security systems. This also applies to Ecuador although there have been attempts to include informalsector workers in the social protection system. ${ }^{1}$ Another main trait of social protection in Ecuador is the relevant role of families. Martínez (2007) worked on a typology for Latin America that defined Ecuador's welfare regime as "familiarist" due to the great weight placed on family and community arrangements for risk management and the provision of social services in the framework of an excluding labour market and weak public policy. These arrangements range from the substitution of expenses through women's unpaid work to migration (Vásconez 2005; Vásconez et. al. 2005).

The role of the state and the market in welfare provision and the degree of universalism in social policy have not remained constant. Rather, they have been adapted to the economic and development models adhered to at different moments. For example, the rise of structuralism (1940s - late 1970s) was accompanied by an endogenous development model and increased state interventionism in economics and social policy. Filgueira (2013) labelled it as a period of "narrow corporatism" for the region because social protection benefits were granted based on affiliation to specific unions or trades and favoured public sector workers. However narrow, it was a period when the state enlarged the ranks of those it provided protection for. Within this regional context, Filgueira (1998) argued Ecuador had an "excluding"

\footnotetext{
${ }^{1}$ In 1968, the Ecuadorian Social Security Institute (IESS, for its Spanish acronym) ran its first pilot program called the Peasant Social Security or Seguro Social Campesino, which has successfully incorporated over a million rural workers and small-scale fisherman. In 2015, unpaid domestic workers were included in the social security pension scheme as voluntary affiliates through the Organic Law for Labour Justice and Recognition of Work in the Home, or Ley Orgánica para la Justicia Laboral y Reconocimiento del Trabajo del Hogar.

${ }^{2}$ The other two types of welfare regimes in Latin America are the state-productivist regime, in which the state invests in human capital for their insertion into labour markets, and the state-protectionist regime, in which the state also invests in human capital but emphasizes the de-commodification of social protection.
} 
regime characterized by elitist social security and health systems that reinforced social stratification and exclusion in access to social services.

In the 1980s, with the predominance of a neoliberal economic and development model, attempts to promote a more active state and the expansion of social protection were replaced with a general tendency towards focalization, deepening the stratifying and stigmatizing effects of social policy (Sojo 1990). Between 1983 and 2006, social policy in Ecuador promoted what Filgueira (2013) called "restricted focalization". At a regional level, the state was pushed to play a "residual" role in social policy as the market and international institutions, including NGOs, became predominant. Public services like health and education were redefined as services exclusively for "the poor", while public spending was reduced for the sake of fiscal stability. On the other hand, in the modest formal labour market, Ecuador witnessed setbacks in social protection through the promotion of labour flexibility, encouraged as a way to lure in foreign investment.

A third moment in the development of social protection in Ecuador was inaugurated in 2007 through a series of executive decrees that secured immediate investment for the failing education and health systems, ${ }^{3}$ and consolidated in 2008 with the re-writing the country's political Constitution. Since then, Ecuador witnessed an expansion of social protection and a shift towards a universal model (particularly for education and healthcare). The Constitution paved the way for a new distribution of responsibilities among the different spheres of welfare provision (state, market, family-community), favouring the state's role in the provision of welfare and redefining social services as social and economic rights. Likewise, the government of then president Rafael Correa enshrined more labour protection through the prohibition of outsourcing and any form of precarious work, ${ }^{4}$ increased wages to guarantee coverage of the basic consumer basket, and increased access to social security. ${ }^{5}$ Filgueira (2013) referred to this shift as a second experiment to build "social citizenship" based on universalism and as a "political solution" to the inclusion crisis generated by the austerity policies implemented in the previous decades. An experiment Filgueira (2013) recognized as incomplete because states were unable to modify the contributory pillars of social protection and to untie access to social security from the logic of the market.

\footnotetext{
${ }^{3}$ In March and May 2007, president Rafael Correa declared the education and health sectors in a state of emergency ordering the immediate release of funds for both public systems. In that first moment, US $\$ 40$ million were disbursed to the Ministry of Public Health (MSP for its Spanish acronym) and US\$80 million to the Ministry of Education to repair infrastructure and obtain necessary equipment and supplies.

${ }^{4}$ In the framework of re-writing the Constitution, legislators approved the prohibition of outsourcing and precarious labour. In relation to this mandate, the then Ministry of Labour Relations began conducting a series of inspections nation wide.

${ }^{5}$ The 2008 Constitution defines social security as the state's duty and as a right of all inhabitants (Art. 55) paving the way for the necessary expansion in coverage. In 2014, through IESS Resolution 467 , the government established the voluntary affiliation process for those without a formal job, a direct employer, or people living abroad.
} 
Ecuador still shows high rates of informal labour and, consequently, a stratified social security system (Minteguiaga and Ubasart-González 2013) while attempts towards the de-commodification and universalization of access to social services did not replace "pro-poor" targeting or the reliance on the family and community for social protection (Minteguiaga and Ubasart-González 2014). Access to unemployment, maternity and paternity leave, and pensions depends on individual contributions to the IESS, either as employees or voluntary affiliates. Only health benefits in kind are accessible to all residents (either national citizens or foreign residents ${ }^{6}$ ), regardless of employment or contributions to the public health system. Benefits to guarantee minimum resources, such as the Assistance Pension and the Human Development Bonus (HDB), are the only non-contributory benefits but they are reserved only to those who can prove they are living in a condition of extreme poverty and must be either Ecuadorian nationals or refugees.

\subsubsection{Migration History and Key Policy Developments}

Migration outflows were regular throughout Ecuador's modern history until 1.5 million people fled the country following the economic and financial crisis of the late nineties when unemployment reached $15 \%$ and the poverty rate $56 \%$ (Jokisch 2014). Spain became the main destination country, accounting for $45.1 \%$ of Ecuadorian emigrants, while $28.6 \%$ settled in the United States (Herrera et al. 2012). The massive outflow of people seeking work opportunities had negative effects on some communities' social fabric and positive effects on the economy through remittances that peaked in 2007, reaching US\$3.3 billion (Jokisch 2014). With the onset of the 2008 international financial crisis and in the context of Ecuador's growing economy, the emigration trend reversed. Between 2009 and 2012, the number of Ecuadorian emigrants dropped by 31\% (OAS 2015) and in 2010, during Ecuador's last census, the government registered at least 72,000 people who had returned from abroad. In light of the influx of returning migrants, the Ecuadorian government implemented the "Welcome home" plan to assist returnees.

Ecuador has also been an important receiving country, especially for Colombians seeking refuge after being forcibly displaced by the country's decades-long internal armed conflict (1960 - on going) and drug trafficking-related violence. The Ministry of Foreign Affairs and Human Mobility (2018) estimates that in 2018, over 500,000 Colombians lived in Ecuador. Of them, only 200,000 enjoy a regular status. ${ }^{8}$ Most

\footnotetext{
${ }^{6}$ However, since September 2018, having public or private health insurance has become a requirement for obtaining temporary and permanent residency.

${ }^{7}$ The plan allowed returning migrants to enter the country with all their belongings without paying import taxes, provided a "housing grant" and credit for entrepreneurs, among others (Sanchez 2014).

${ }^{8}$ Over 60,000 have been granted refugee status, 45,486 have Mercosur visas, 18,663 have family reunification visas (visas de amparo), and 6773 have been granted humanitarian or international protection visas.
} 
recently, Ecuador has become a destination and transit country for Venezuelans who are facing a prolonged economic crisis. Between 2014 and 2018, over three million Venezuelans left their country of origin. The United Nations High Commissioner for Refugees (UNHCR) has registered Ecuador among the top four destinations for Venezuelans, preceded by Colombia, Chile, and Peru; there are approximately 221,000 Venezuelan migrants and refugees in Ecuador (Stein 2018). Of these, only 97,000 have obtained a residence permit, allowing them to work legally. The other two largest groups of immigrants (Cubans and U.S. citizens) are marginal in comparison. ${ }^{9}$

In 2008, through the new Constitution, Ecuador laid out a series of protections for immigrants. It guaranteed non-discrimination on the basis of migratory status (article 11), recognized the right to migrate and established that "no human being will be considered illegal" (article 40), and advocated for the principle of universal citizenship and free movement (article 416). In 2013, the Ministry of Foreign Affairs and Human Mobility (hereinafter referred to as the MFA) began drafting the Human Mobility Law. ${ }^{10}$ The bill, approved in February 2017, ratified the principles of universal citizenship, free movement, non-criminalization, and non-discrimination. It also eased entry for South Americans, requiring only a national Identity Document (ID) card and granting them an automatic 180-days visa. However, Venezuelan and Colombian immigrants come to Ecuador in search of jobs and the visa does not allow them to work legally. Despite the possibility of applying for a temporary and then permanent residency once in Ecuador, international organizations point to high costs as a serious obstacle to achieving a regular migratory status, leaving immigrants "without rights and access to services, and therefore vulnerable to all forms of exploitation and abuse, violence, and discrimination" (Stein 2018: 11).

In August 2018, amid rising xenophobia targeting Venezuelans, the government of Lenin Moreno announced Ecuador would begin requiring passports for entry. Human rights groups succeeded in eliminating the requirement but the MFA later issued a ministerial agreement requiring Venezuelans' national IDs to be validated by either the Venezuelan government or a recognized international institution. In January 2019, the government again announced extra requirements that single out Venezuelans by requesting their police records. ${ }^{11}$ Finally, since August 2019 the Ecuadorian government is requesting visas for Venezuelans. In order to obtain a visa they need a passport and police records. The measure will likely produce an increase of irregular migratory inflows and make Venezuelans even more vulnerable to violence, human trafficking and other forms of abuse. Ramírez (2018) contends that this policy shift responds to a global trend favouring a "control and security"

\footnotetext{
${ }^{9}$ There are roughly 5000 Cubans and 4000 U.S. citizens residing in Ecuador.

${ }^{10}$ This law replaced four previous laws: the Travel Documents Law, Naturalization Law, Migration Law, and Immigration Law.

${ }^{11}$ The announcement was made after the murder of an Ecuadorian woman at the hands of her romantic partner (a Venezuelan man). Feminist groups protested against a rising trend of femicides and gender-based violence a few days later. They also rejected the government's measure for promoting xenophobia.
} 
approach to migration that portrays immigrants "as those responsible for altering order and stability as well as placing public social services like health, education, and social security at risk" (12). ${ }^{12}$

\subsection{Migration and Social Protection in Ecuador}

IESS affiliates, whether national citizens or foreigners residing in Ecuador, are the most protected category of population in terms of access to social protection benefits. They have access to health benefits in kind, paid maternity and paternity leave, old age and disability pensions, and unemployment. Affiliation for full and part time workers is a legal obligation of every employer in Ecuador; not fulfilling this obligation within the first 15 days of employment is considered a criminal offense and carries a penalty of three to five basic salaries for each non-affiliated worker and 3-7 days of prison (articles 243 and 244 of the Penal Code or Código Penal). ${ }^{13}$ However, it is not easy to secure the right to work as an immigrant in Ecuador.

Only recognized refugees are guaranteed the right to work and need no authorization or labour certification to be able to work. ${ }^{14}$ All other foreigners must have a work visa (e.g. 12-VI or 9-IV) or temporary residency visa (e.g. Southern Common Market or Mercosur, Union of South American Nations or Unasur, and EcuadorVenezuela Statute) to work legally. These are granted to immigrants who have secured labour contracts in the country and does not protect vulnerable, nonprofessional immigrants. Work visas are granted to professionals with high technical/educational levels ${ }^{15}$ while the Mercosur and Venezuelan Migrant Statute visas are granted only with proof of a source of income for at least the minimum wage. Foreign residents can work as public servants only with a prior report from the hiring institution and a permit issued by the Labour Ministry. ${ }^{16}$ To work in the private sector they need a "certification by the Labour Ministry's National Director of Employment and Human Resources" stating that the hire does not affect the "national policy on employment and human resources." 17

\footnotetext{
${ }^{12}$ Generally, there are rising numbers of deportations and non-admissions. While in 2017 the Interior Ministry registered 26 deportations and 234 non-admissions, by April 2018 it registered 191 deportations and 22 non-admissions (Ramírez 2018).

${ }^{13}$ Both sanctions will only be enforced if the employer does not pay its debt to the IESS within $48 \mathrm{~h}$ after being notified.

${ }^{14}$ As established through Executive Decree 1182 (2012) and the Labour Ministry's ministerial agreement 118 (2013).

${ }^{15}$ Migrants who wish to work in Ecuador must register their higher education degrees at the Secretariat of Higher Education, Science, and Technology.

${ }^{16}$ As stated by article five of the 2016 Organic Law on Public Service or Ley Orgánica de Servicio Público.
}

${ }^{17}$ Article 560 of the Labour Code or Código del Trabajo. 
Only refugees have access to non-contributory social protection benefits like the HDB or the Assistance Pension. In general, accessing social benefits in Ecuador cannot affect an immigrant's application for temporary and permanent residency, family reunification, or citizenship because the MFA (responsible for granting visas, residency, and nationality) does not crosscheck information with the education or health ministries that provide the only benefits immigrants can access.

Ecuadorian citizens residing abroad have no access to non-contributory social protection benefits. They can only access MSP health services if they are in Ecuador regardless of residency. The only social protection benefits they can secure are those linked to being an IESS affiliate because they can voluntarily affiliate to IESS gaining access to health services in Ecuador and access to IESS pensions. However, they don't access unemployment benefits, or maternity and paternity benefits. Ecuador has signed bilateral social security agreements with Spain, the Netherlands, Uruguay, Venezuela, Chile, Peru, Paraguay, and Colombia that allow immigrants from these countries and Ecuadorians who have worked in these countries to totalize the periods worked across territories to access their contributory old age, invalidity and montepío ${ }^{18}$ pensions.

Ecuador is part of several regional integration organizations: associated member of MERCOSUR and full member of the Andean Community (CAN), UNASUR, ${ }^{19}$ the Latin American Integration Association (ALADI), and the Community of Latin American and Caribbean States (CELAC), but no benefits apply exclusively to nationals of one Member State of these regional integration bodies who move to another Member State. In 2004, the CAN created the Andean Committee of Social Security Authorities and between 2013 and 2016, the Committee worked on a regulatory framework for shared norms that would guarantee social security to "community" migrants working within the CAN. However, no concrete measures have been announced so far. In 2009, UNASUR created the South American Sectorial Council for Social Development, in which Member States share experiences in the field of social protection. However, no specific policies of intra-regional social security coordination have emerged from this space. ${ }^{20}$

In 2008, Ecuador signed the Multilateral Ibero-American Agreement on Social Security ${ }^{21}$ which includes Argentina, Bolivia, Brazil, Chile, El Salvador, Spain, Paraguay, Peru, Portugal, and Uruguay. According to the Ibero-American Organization for Social Security or OISS (2017), the agreement, "effectively applied" in Ecuador since 2011, is applicable to social security benefits in case of invalidity, old age, survival, job-related accidents and illness and it ensures the

\footnotetext{
${ }^{18}$ Pension granted to the children, widow or dependent parents of an IESS affiliate or pensioner.

${ }^{19}$ Since March 2019, Ecuador followed through all formal steps for its withdrawal from UNASUR, but it is not yet finalized.

${ }^{20}$ UNASUR has been practically paralyzed since 12 Members States announced their temporary withdrawal in 2018 so progress towards an inter-connected social protection system is highly unlikely now.

${ }^{21}$ Available here: http://www.seg-social.es/Internet_1/Normativa/index.htm?dDocName=147177 $\& \mathrm{C} 1=1001 \& \mathrm{C} 2=2013 \& \mathrm{C} 3=3053 \#$ documentoPDF
} 
possibility to totalize periods and "export" the benefits. However, according to the IESS website, years worked in Argentina, Bolivia, Brazil, El Salvador, and Portugal are not being totalized and benefits (pensions) are not sent to other countries. No social security benefit in Ecuador is exportable. Ecuadorians living abroad can enter the social security pension scheme by voluntarily affiliating to the IESS, but they cannot export the pension; they must claim it in a national bank account once they've met the necessary requirements.

Non-contributory social protections (HBD or the old-age Assistance Pension) benefits are granted to the "poor" citizen, which is the second most protected category. However, only Ecuadorians and refugees who certify living in extreme poverty are eligible to access these benefits that don't represent even half of the consumer basket. ${ }^{22}$

\subsubsection{Unemployment}

The Unemployment Insurance scheme went into effect in March 2016 through the Organic Law for the Promotion of Juvenile Labour, Exceptional Regulation of the Work Day, Unemployment and Unemployment Insurance. ${ }^{23}$ Only employed workers affiliated to the IESS -national citizens or foreigners- can claim this benefit. Those who are voluntarily affiliated or fall under special social security regimes don't have access to unemployment insurance as they don't have an employer. Furthermore, military staff and police officers cannot apply for the unemployment insurance benefit as they fall under two special social security regimes that do not operate within the IESS: the Social Security Institute of the Armed Forces (ISSFA) and the Social Security Institute of the Police (ISSPOL), which have their won medical centres, hospitals and higher pensions.

To receive Unemployment Insurance, IESS affiliated workers must register 24 monthly contributions, 6 of which must be consecutive and immediately before claiming the benefit. Claimants must be involuntarily unemployed for 60 days. There are no explicit residency or age requirements, nor do beneficiaries have to prove job search or register as job seekers. The benefit can be claimed on day 61 of unemployment and there is a 30-day waiting period for the first payment. It lasts for 5 months and it is a percentage ${ }^{24}$ of an average of the beneficiary's last 12 salaries.

Before the Unemployment Insurance was created, IESS affiliates could withdraw accumulated personal savings in the Fondo de Cesantía, or Unemployment

\footnotetext{
${ }^{22}$ The HDB represents a cash transfer of US\$50 to US\$150, while the Assistance Pension is US\$100. According to the National Institute for Statistics and Census (INEC) the basic consumer basket for August 2018 is US\$710.76.

${ }^{23}$ Ley Orgánica para la Promoción del Trabajo Juvenil, Regulación Excepcional de la Jornada de Trabajo, Cesantía y Seguro de Desempleo.

${ }^{24} 70 \%$ for the first month, $65 \%$ for the second one, $60 \%$ for the third, $55 \%$ for the fourth and $50 \%$ for the fifth and last month.
} 
Fund. ${ }^{25}$ When IESS affiliates claim their Unemployment Fund the IESS transfers the total amount in the personal saving account to the affiliate's bank account. The two benefits are not mutually exclusive. If the beneficiary remains unemployed after receiving Unemployment Insurance, he/she can access his/her personal fund. Access to the fund requires 24 monthly contributions and 60 days of unemployment. This benefit, like all others, is not exportable. Nationals residing abroad can only access it if they have a bank account in Ecuador, where the benefit can be deposited. Nationals or foreigners who are entitled to receive the Unemployment Insurance can temporarily leave the country without affecting eligibility requirements.

\subsubsection{Health Care}

Health is conceived as a universal right granted to everyone, independently of their residency, employment status or nationality. According to Ecuador's 2008 Constitution, the public healthcare system includes social security, ${ }^{26}$ and MSP services. The MSP only provides benefits in kind in case of sickness, while the IESS provides both benefits in kind and cash benefits for sickness and invalidity. We focus on benefits in kind provided by the MSP and cash benefits provided by the IESS as these are the more general benefit providers in the health area.

Universal public healthcare services managed by the MSP are financed through national revenue. The 22nd transitional provision of the 2008 Constitution established that the national budget for the health system had to be increased by $0.5 \%$ of Gross National Product (GNP) yearly, until reaching no less than $4 \%$ of the GNP. This measure aimed to reverse the tendency to underfund the public healthcare system, which before 2008 was focalized for people living under conditions of poverty. In order to access the MSP health services, national and foreign residents only have to show their ID.

Despite its stated universal character, there are several reports of refugees being denied their right to public healthcare (Jaramillo 2015; ODNA 2010). Organizations such as Catholic Relief Services and the Scalabriniana Mission have reported that refugees seeking medical attention are routinely rejected by public hospitals and health centres, or have to wait more than nationals to access services (Jaramillo 2015). Immigrants without refugee status also face restricted access to universal health care and education services (Cardoso and Mendiola 2008; Sánchez 2013; Benavides 2007). The 2017 Human Mobility Law stipulates health providers cannot refuse to provide emergency medical attention to migrants. However, article 64 states that for a foreigner to be granted a permanent residence, the person must either affiliate to the IESS or get a private health insurance. In April 23, 2018

\footnotetext{
${ }^{25}$ While the unemployment insurance is financed $2 \%$ by the worker's salary contribution and $1 \%$ by the employer, the unemployment fund is financed only by the worker's $2 \%$.

${ }^{26}$ The IESS, the Social Security Institute of the Police (ISSPOL), and the Social Security Institute of the Armed Forces (ISSFA) health services and facilities, which are public but restricted.
} 
Ecuador's president Lenin Moreno issued an executive decree making the health insurance requirement for foreigners in Ecuador mandatory. This marks a clear restriction on foreigners' access to MSP health services.

Access to IESS health benefits in kind is restricted to IESS affiliates and pensioners, regardless of whether they are nationals or foreigners, employed or voluntary affiliates. Ecuadorian citizens and non-national residents can become voluntary IESS affiliates as long as they have an Ecuadorian ID. ${ }^{27}$ Affiliates must have registered at least 3 monthly contributions, while pensioners can access the benefits immediately. Since $2010,{ }^{28}$ the affiliate's children and registered spouse, either nationals or foreigners, can also access IESS health benefits in kind as long as the affiliates contribute an additional $3.41 \%$ for spouses or cohabitants (coverage for children under 18 is free of charge). Pensioners must contribute $4.15 \%$ of their pensions for their spouses and $3.41 \%$ for their children under 18. For both MSP and IESS health benefits in kind, the beneficiary is not required to pay at any moment and IESS affiliates and pensioners can use private health service providers that have entered into prior agreement with the IESS.

Cash benefits in case of sickness are granted to employed workers affiliated to the IESS, regardless of nationality. These benefits are granted in the form of paid licenses for a period of up to 185 days. Claimants must have at least 6 monthly and continuous contributions immediately preceding sickness. There is no explicit residence requirement, although the IESS affiliate, regardless of nationality, must be working in Ecuador in order to access it. If the affiliate moves abroad and the license has not been paid, the IESS will make the payment in a national bank account.

If sickness turns into prolonged incapacity, the affiliate can receive a transitory incapacity subsidy for 1 year. This is prior to receiving the Invalidity Pension granted to IESS affiliates who are not receiving other pensions and have 60 monthly contributions (out of which at least 6 of them immediately prior to the incapacity) or 120 monthly contributions (if the incapacity happens between 6 and 24 months of the affiliates' last contribution). There is no explicit residency requirement for accessing the Invalidity Pension. The main condition of access is to be "incapacitated to procure through a job proportional to his or her capacities, strengths, theoretical and practical formation, a remuneration at least half of the remuneration a healthy worker in similar conditions obtains in the same region" (Social Security Law, article 186).

The National Evaluation Commission evaluates the request for the Invalidity pension. If it is approved, the affiliate has to accept the pension agreement and resign from his/her job to start collecting the pension. To prove the existence of a permanent invalidity, the affiliate must undergo periodic assessments. Invalidity pensions and the transitory subsidy are calculated taking the average of the best

\footnotetext{
${ }^{27} \mathrm{~A}$ foreigner who wants to get an Ecuadorian ID must go to the Civil Registry (Registro Civil) with a valid passport, a valid visa and an ID issuance order. For the issuance order, the foreigner must have a visa for temporary or permanent residency, certification of having public (IESS) or private health insurance (since September 2018), and an updated list of migratory movement.

${ }^{28}$ Resolution $\mathrm{N}^{\circ} \mathrm{CD} 334$ of the IESS Directive Council.
} 
5 years of reported salaries. Calculations differ depending on the years contributed to the IESS. Nationals and foreigners who are IESS affiliates have an equal right to the transitory incapacity subsidy and the invalidity pension; the conditions to claim these benefits are the same for all IESS affiliates. These benefits are not exportable, but national and foreigner IESS affiliates who move abroad can continue receiving the benefit as long as they have a bank account in Ecuador.

Finally, there are two non-contributory health-related cash benefits. The disability Assistance Pension is granted to Ecuadorians or refugees living in conditions of extreme poverty that have a disability of at least a $40 \%$, whereas the Joaquin Gallegos Lara Bonus is granted to Ecuadorians with severe physical disability (at least $75 \%$ ) or intellectual disability (at least 65\%), catastrophic disease or to children under 14 with HIV-AIDS. The former receive US\$100 and the latter US\$ 240 monthly. These social protection benefits are not available to foreigners residing in the country or to nationals residing abroad.

\subsubsection{Pensions}

There are two types of old-age pensions in Ecuador: the contributory pensions granted to IESS affiliated and the non-contributory pensions managed by the Ministry of Social and Economic Inclusion (MIES) granted to people living under conditions of extreme poverty. IESS pensions are financed through the "intergenerational solidarity" scheme, under which the monthly pensions of "passive workers" or pensioners are financed by the monthly contributions paid by active workers affiliated to the IESS and state financial contributions. The 2001 Social Security Law sought to establish a mixed system for financing pensions, but this system was declared unconstitutional in 2005. Non-IESS pensions are managed by the MIES and financed through tax revenue. In 2012, the National Assembly approved the Law for the Redistribution of Social Spending, ${ }^{29}$ which enabled the increase of the amounts paid for non-contributory old-age Assistance Pension from US\$30 to US $\$ 50$ by capturing part of private banks' utilities. In December 2017, the Executive Decree 253 increased the Assistance Pension to US\$100.

To access the IESS old-age retirement pension, the affiliate must either be 70 years old and have contributed during 10 years; or have 40 years of contributions, with no age requirement. This applies to voluntary affiliates, including Ecuadorians living abroad, which means an Ecuadorian can live abroad all his/her life and if they contributed for the minimum 10 years required and reached the age of 70 they have access to the old-age retirement pension. The pension is calculated using an average of the best 5 years of reported salaries and the amount varies according to years contributed.

${ }^{29}$ Ley para la Redistribución del Gasto Social. 
Once the affiliate acquires the right to become a pensioner, there is no residency requirement although the pension cannot be exported. A retiree can receive his/her pension in an Ecuadorian bank account regardless of where he/she is residing. These pensions can be accessed from abroad if the retiree has an international ATM card or if he/she transfers the money after the IESS deposited it in an Ecuadorian bank account.

Ecuadorians or refugees of at least 65 years of age who can prove they live in "extreme poverty" through the Social Registry ${ }^{30}$ can claim the non-contributory oldage assistance pensions. Refugees are the only foreigners who can claim this benefit and Ecuadorians residing abroad do not have access to non-contributory old-age assistance pensions. There are no qualifying periods of contributions or explicit residency requirements. In order to obtain this pension (of US\$100 per month), eligible claimants must show their national ID and wait for the in situ survey to prove living in "extreme poverty."

\subsubsection{Family Benefits}

There are several types of family-related benefits in Ecuador and the eligibility conditions applied in each case vary from one benefit to another. Paid maternity leave is granted to employed workers affiliated to the IESS who have at least 12 months of uninterrupted contributions prior to giving birth. The benefit lasts for 12 weeks ${ }^{31}$ and there is no explicit residency requirement. National and foreign IESS affiliates have equal access to maternity and paternity benefits. None of these benefits are exportable, but individuals can still temporarily move abroad while receiving the maternity/paternity paid leaves in an Ecuadorian bank account. In the public sector, the employer covers $40 \%$ of the worker's wage while the IESS covers $60 \%$. In the private sector, the employer covers $25 \%$ and the IESS $75 \%$, respectively.

Eligibility conditions for paid paternity leave are the same as for the maternity leave. The benefit lasts 10 days, with a possibility of extension in particular circumstances. Like mothers, fathers can claim an optional unpaid leave of up to 9 months. Additional benefits for parents are the paid hourly permits to care for children or the breastfeeding permits for up to $2 \mathrm{~h}$ daily for 12 months after paid maternity leave is over. There are no parental benefits (i.e. benefits to replace income for parents who want to take care of their children after maternity or paternity benefits) in Ecuador.

\footnotetext{
${ }^{30}$ The Social Registry is a database that uses a series of indicators (e.g. living conditions, schooling, income, properties, and access to public services) to create a wellbeing index for determining who can benefit from different social programs.

${ }^{31}$ Affiliates can access an additional 36 weeks without pay, but with the guarantee they will not be fire during the unpaid leave. There are situations that justify an extension of maternity leave (multiple births, C-section, premature births, etc.). Foster parents have the right to a paid licence for 15 days, which begin after the child is legally transferred.
} 
The Human Development Bonus can be considered a child benefit because it is granted to heads of family with children (under 18) who live in "extreme poverty" (the living conditions are certified through the Social Register). The benefit is only granted to resident Ecuadorians and refugees, until the family ceases to live under extreme poverty. Beneficiaries must certify periodic health checks and that the children are going to school. The HDB has a flat component of US\$50 and a variable component: US\$30 for every child between 0 and 5 years old for up to 3 children, US\$10 for every child between 5 and 18 for up to three children. The value of the variable component is reduced by $10 \%$ for every extra child. The maximum amount for the benefit is of US\$150. People who receive other cash transfers (e.g. Assistance Pension) are not eligible to get the variable component.

\subsubsection{Guaranteed Minimum Resources}

In Ecuador there are no guaranteed minimum resources scheme, but there are four programs that provide conditional cash transfers: the Assistance Pension, the Human Development Bonus, the Joaquín Gallegos Lara Bonus (BJGL), and Eloy Alfaro Scholarship Program. These benefits are covered through the national budget, specifically through tax revenue.

The BJGL recognizes two subjects of intervention: rights holders, who are people with serious disability (75\% physical disability or $65 \%$ of intellectual disability), or catastrophic illness, or children under 14 with HIV-AIDS and the caregivers. The transfer is equivalent to US\$240. The transfer is deposited either to the rights holder or to the caregiver depending on the degree of dependency of the person with disability. From its creation in 2010 the transfer only benefits people within the Social Registry database. In 2014, it was established that the program could benefit foreigners, but only in an exceptional way and "when there are sufficient financial resources". ${ }^{32}$ The Eloy Alfaro National Scholarship is given to members of households that receive the HDB or who can prove a condition of poverty despite not receiving the bonus and are enrolled in a national university. The transfer started out as a minimum wage, currently US $\$ 394$, but was later reduced to half the minimum salary. The program was designed to only benefit Ecuador citizens and refugees. ${ }^{33}$

\footnotetext{
${ }^{32}$ This was stipulated in resolution 19 of the extinct Technical Secretariat for Disabilities (Secretaría Técnica de Discapacidades), which ran the program until 2016, when it was transferred to the MIES.

${ }^{33}$ The program has not been eliminated, but it was not launched in 2018 .
} 


\subsection{Conclusions}

The Ecuadorian social protection system is a highly stratified one in which IESS affiliates (whether Ecuadorian or foreigners) enjoy most benefits. This effectively means that social protection benefits are contributory and depend on a person's favourable insertion in the labour market. Given the existence of an important informal labour market, the overall system has a low coverage. To illustrate, the National Institute of Statistic and Census revealed that only $42 \%$ of all workers were affiliated to the IESS in 2018. Furthermore, there were roughly 4 million affiliates and 400,000 pensioners, while 8.2 million people made up the total labour force according to World Bank data (2017). This means that less than half of the working-age population has access to unemployment insurance, family benefits, sickness subsidies, old age and invalidity pensions.

State attempts to broaden coverage and access to social protection during the 2007-2017 period relied on the existing structure of benefits. Affiliation to IESS became more inclusive through different forms of voluntary affiliation and new benefits were created. Non-contributory benefits like the HDB -established in the late nineties to make up for the elimination of the key subsidies to gas, fuel, and electricity- increased its coverage, but they continue to be too limited to provide adequate social protection or the necessary conditions to overcome poverty. Efforts to modify and expand social protection through the universalization of access to health and education to address the issue of socio-economic inequality did not displace the focus on poverty that social policy based on focalized programs has. However, during these years there was some innovation in this field through the creation of interconnected programs that sought to address the problem of structural inequality like the Eloy Alfaro Scholarship. Regrettably, in the context of a new wave of austerity measures inaugurated in late 2017, this program has been discontinued.

Universal coverage for health, implemented since 2007, provides a general base for social inclusion and protection for all individuals including immigrants, but recent legal reforms seek to exclude immigrants by requiring them to either affiliate to the IESS or get private health insurance in order to apply for a residence permit. Migrants in general, foreigners in Ecuador and Ecuadorians abroad, are the least protected group of people. Social protection benefits granted to Ecuadorians living abroad are very limited, and they are dependent on monthly contributions to the IESS as voluntary affiliates. Even contributing, they only gain access to pensions when they meet the necessary requirements. They can't access maternity and paternity benefits, unemployment, or health benefits.

In Ecuador, there are no political parties with explicitly anti-immigrant platforms. However, the current minister of labour has made references to a "moratorium" to replace "foreign irregular workers with young Ecuadorian affiliated workers" (Enriquez 2017). Low skilled workers who come to Ecuador as immigrants are usually denied IESS affiliation by employers who take advantage of irregular migratory status to pay them less than the minimum wage or to avoid paying IESS affiliation (Zambrano 2018). As previously mentioned, there is a worrying 
trend of scapegoating Venezuelan immigrants. This has happened at all levels of political life, from forms of harassment in the workplace to mob violence ${ }^{34}$ and restrictive measures announced against Venezuelans by high-level authorities, including the president. Any "moratorium" or "replacement policy" would further deteriorate access to social protection benefits by creating an incentive to refrain from hiring Venezuelan immigrants. Immigrants who access IESS social protection are mostly those with a high level of education.

In the past years, the country also witnessed a return to a more "restrictive focalization." As cash transfers within the HDB and the Assistance Pension increased in value, it narrowed its target population to people living in extreme poverty, first in 2013 and then in 2017. Additionally, since 2017, there have been attempts to reduce the provision of labour-related protections. In September 2017, the Executive Decree 135 ordered a freeze on public hiring, a prohibition of new hires, and the elimination of provisional appointments. Since then, there have been several layoffs in the public sector and processes to privatize public companies. Because access to a formal job is what mainly determines access to social protection benefits, measures that increase unemployment have direct negative consequences on welfare and social protection. With the recent developments and setbacks in the field of social and migratory policy, Ecuador's social protection system is deepening its exclusionary, residual, and familiarist character.

Acknowledgements This chapter is part of the project "Migration and Transnational Social Protection in (Post)Crisis Europe (MiTSoPro)" that has received funding from the European Research Council (ERC) under the European Union's Horizon 2020 research and innovation programme (Grant agreement No. 680014). In addition to this chapter, readers can find a series of indicators comparing national social protection and diaspora policies across 40 countries on the following website: http://labos.ulg.ac.be/socialprotection/.

\section{References}

Barrientos, A. (2004). Latin America: A liberal-informal welfare regime? In Gough et al. (Eds.), Insecurity and welfare regimes in Asia, Africa and Latin America. Social policy in development contexts (pp. 121-168). Cambridge: Cambridge University Press.

Benavides, G. (2007). Informe sombra al primer informe del Estado ecuatoriano sobre cumplimiento de la Convención internacional sobre la protección de los Derechos de Todos los Trabajadores Migratorios $y$ sus Familiares. http://repositorio.uasb.edu.ec/bitstream/10644/472/1/ BenavidesInforme $\% 20$ sombra\%20primer\%20informe $\% 20$ del $\% 20$ Estado\%20ecuatoriano $\% 20$ convenci\%C3\%B3n\%20trabajadores\%20migratorios.pdf. Accessed 20 Sep 2018.

Cardoso, L. \& Mendiola, M. (2008). Grupos en situación de especial protección en la región andina: migrantes. https://pingpdf.com/pdf-grupos-en-situacian-de-especial-proteccian-en-laregian-andina.html. Accessed 20 Sep 2018.

\footnotetext{
${ }^{34}$ Most recently, mobs attacked Venezuelan families in the city of Ibarra following the murder of an Ecuadorian woman by her Venezuelan partner.
} 
Enriquez, C. (2017, June 6). Ministro de Trabajo: 'No es necesario volver a la contratación a plazo fijo.' El Comercio.

Estrella, E., \& Crespo-Burgos, A. (2002). El Ministerio de Salud Pública y la OPS/OMS en el Ecuador. In Benítez et al. (Eds.), El cóndor, la serpiente y el colibrí. La OPS/OMS y la salud pública en el Ecuador en el Siglo XX (pp. 229-241). Quito: OPS.

Filgueira, F. (1998). El nuevo modelo de prestaciones sociales en América Latina: eficiencia, residualismo y ciudadanía estratificada. In B. Roberts (Ed.), Ciudadanía y Política Social (pp. 71-11). San José: FLACSO y SSRC.

Filgueira, F. (2013). Los regímenes de bienestar en el ocaso de la modernización conservadora: posibilidades y límites de la ciudadanía social en América Latina. Revista Uruguaya de Ciencia Política, 22(2), 17-46.

Herrera, G., Moncayo, M. I. \& Escobar, A. (2012). Perfil migratorio del Ecuador 2011. http:// publications.iom.int/bookstore/free/Perfil_Migratorio_del_Ecuador2011.pdf Accessed 31 Jan 2019.

Jaramillo, A. (2015, May 17). Los inmigrantes tienen barreras para acceder a servicios de salud. El Comercio.

Jokisch, B. (2014). Ecuador: From mass emigration to return migration? https://www.migrationpolicy.org/article/ecuador-mass-emigration-return-migration. Accessed 1 Feb 2019.

León, M. (2002). Los beneficios del Bono Solidario ante la crisis. Quito: SIISE.

León, M., \& Alomia, D. (2008). El Bono de Desarrollo Humano en el Ecuador. Quito: MIES.

Martínez, J. (2007). Regímenes de Bienestar en América Latina. Madrid: Fundación Carolina.

Ministerio de Relaciones Exteriores y Movilidad Humana. (2018). Plan Nacional de Movilidad Humana. https://www.cancilleria.gob.ec/wp-content/uploads/2018/06/plan_nacional_de_ movilidad_humana.pdf. Accessed 1 Feb 2019.

Minteguiaga, A., \& Ubasart-González, G. (2013). Revolución ciudadana y régimen de bienestar en Ecuador (2007-2012). Buenos Aires: CLACSO.

Minteguiaga, A., \& Ubasart-González, G. (2014). Menos mercado, igual familia. Bienestar y cuidados en el Ecuador de la Revolución Ciudadana. Revista Íconos, 50, 77-96.

Naranjo, M. (2008). Ecuador: Reseña de los principales programas sociales y lecciones aprendidas, 2000-2006. Santiago de Chile: CEPAL.

OAS. (2015). SICREMI - Ecuador. http://www.migracionoea.org/index.php/es/component/content/article/44-sicremi/publicacion-2014/informe-parte-ii-es/582-ecuador.html. Accessed 1 Feb 2019.

ODNA. (2010). Niñez y Migración Forzada. https://www.unicef.org/ecuador/MigracionForzada_ web.pdf. Accessed 17 Sep 2018.

OISS. (2017). Guía de aplicación. http://www.oiss.org/IMG/pdf/AF_Guia_de_aplicacion_actualizacion_2017.pdf. Accessed 8 May 2018.

Ponce, J. (1997). La Educación: a la espera de la equidad y la calidad. In S. Cordero \& C. Larrea (Eds.), Pobreza y Capital Humano (pp. 59-86). Quito: STFS.

Ponce, J. (2010). Políticas educativas y desempeño: una evaluación de impacto de programas educativos focalizados en Ecuador. Quito: FLACSO-Ecuador.

Ponce, J., \& Drouet, M. (2017). Evaluación de Impacto del Programa de Escuelas del Milenio. Documento de Política No 01-2017. Quito: Dirección Nacional de Investigación Educativa/ Ministerio de Educación de Ecuador. https://www.siteal.iiep.unesco.org/sites/default/files/ sit_accion_files/ec_0235.pdf. Accessed 1 Feb 2019.

Ponce, J., Bermeo, F., Molyneux, M., \& Thomson, M. (2013). Hacia una reforma del Bono de Desarrollo Humano: Algunas reflexiones. Quito: FLACSO-Ecuador/CARE.

Porras, A. (2010). Las reformas laborales en el Ecuador. Quito: Universidad Andina/Abya Yala.

Ramírez, J. (2018). From the age of migration to the century of security: The emergence of 'control policy with a (in)human face'. URVIO, 23, 10-28.

Sánchez, C. (2013). Exclusiones y resistencias de niños inmigrantes en escuelas de Quito. Quito: FLACSO-Ecuador. 
Sánchez, C. (2014). Policy and institutional frameworks: Country report Ecuador. San Domenico di Fiesole: European University Institute.

Serrano, A. (2013). Análisis de condiciones de vida, el mercado laboral y los medios de producción e inversión pública. Quito: SENPLADES.

Sojo, A. (1990). Naturaleza y selectividad de la política social. Revista de la CEPAL, 1990(41), $183-199$.

Stein, E. (2018). Regional refugee and migrant response plan for refugees and migrants from Venezuela. https://data2.unhcr.org/en/documents/download/67280. Accessed 1 Feb 2019.

The World Bank. (2017). Labor force, total. https://data.worldbank.org/indicator/SL.TLF.TOTL. IN?locations=EC. Accessed 8 May 2018.

Vásconez, A. (2005). Regímenes de bienestar y debate sobre política social en Ecuador. In A. Acosta \& F. Falconí (Eds.), Asedios a lo imposible. Propuestas económicas en construcción (pp. 39-68). Quito: ILDIS-FES/FLACSO-Ecuador.

Vásconez, A., Córdoba, R., \& Muñoz, P. (2005). La construcción de las políticas sociales en Ecuador durante los años ochenta y noventa: sentidos, contextos y resultados. Santiago de Chile: CEPAL.

Velasco, M. (2011). La salud de la población: medio siglo de cambios. In Estado del País. Informe cero. Ecuador 1950-2010 (pp. 323-342). Quito: FLACSO, Contrato Social por la Educación, ESPOL, PUCE, ODNA, Universidad de Cuenca y UNICEF.

Vos, R. (2000). Ecuador 1999. Crisis Económica y Protección Social. Quito: STFS, SIISE, Abya Ayala.

Vos, R., León, M., \& Ramírez, R. (2002). Informe No. 1. Política Social y Tendencias en el Gasto Social: Ecuador 1970-2002. Quito: ISS, STFS, SIISE.

Zambrano, L. (2018, February 12). Decreto para evitar el abuso a los migrantes. El Expreso.

Open Access This chapter is licensed under the terms of the Creative Commons Attribution 4.0 International License (http://creativecommons.org/licenses/by/4.0/), which permits use, sharing, adaptation, distribution and reproduction in any medium or format, as long as you give appropriate credit to the original author(s) and the source, provide a link to the Creative Commons license and indicate if changes were made.

The images or other third party material in this chapter are included in the chapter's Creative Commons license, unless indicated otherwise in a credit line to the material. If material is not included in the chapter's Creative Commons license and your intended use is not permitted by statutory regulation or exceeds the permitted use, you will need to obtain permission directly from the copyright holder.

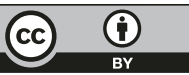

